\title{
EXCESS CAPITAL FLOWS AND THE BURDEN OF INFLATION IN OPEN ECONOMIES
}

Mihir A. Desai

James R. Hines Jr.

Working Paper 6064

\author{
NATIONAL BUREAU OF ECONOMIC RESEARCH \\ 1050 Massachusetts Avenue \\ Cambridge, MA 02138 \\ June 1997
}

This paper was prepared for the NBER conference on "The Costs and Benefits of Achieving Price Stability," New York, NY, February 1997. We thank Kathryn Dominguez, Martin Feldstein, Jeffrey Frankel, Erzo Luttmer, James Poterba, and Shang-Jin Wei for helpful comments on an earlier draft. This paper is part of NBER's research programs in Monetary Economics and Public Economics. Any opinions expressed are those of the authors and not those of the National Bureau of Economic Research.

(C) 1997 by Mihir A. Desai and James R. Hines Jr. All rights reserved. Short sections of text, not to exceed two paragraphs, may be quoted without explicit permission provided that full credit, including $(\mathcal{C}$ notice, is given to the source. 
Excess Capital Flows and the Burden of

Inflation in Open Economies

Mihir A. Desai and James R. Hines Jr.

NBER Working Paper No. 6064

June 1997

JEL Nos. F32, H87, E31

Monetary Economics and Public Economics

\section{ABSTRACT}

This paper estimates the efficiency consequences of interactions between nominal tax systems and inflation in open economies. Domestic inflation changes after-tax real interest rates at home and abroad, thereby stimulating international capital movement and influencing domestic and foreign tax receipts, saving, and investment. The efficiency costs of inflation-induced international capital reallocations are typically much larger than those that accompany inflation in closed economies, even if capital is imperfectly mobile internationally. Differences between inflation rates are responsible for international capital movements and accompanying deadweight losses, suggesting that international monetary coordination has the potential to reduce the inefficiencies associated with inflation-induced capital movements.

Mihir A. Desai

Program in Political Economy

Littauer Center, 2nd Floor

Harvard University

Cambridge, MA 02138

desai@fas.harvard.edu
James R. Hines Jr.

John F. Kennedy School of Government

Harvard University

79 John F. Kennedy Street

Cambridge, MA 02138

and NBER

james_hines@harvard.edu 


\section{Introduction}

Access to the world capital market provides economies with valuable borrowing and lending opportunities that are unavailable to closed economies. At the same time, openness to the rest of the world has the potential to exacerbate, or to attenuate, domestic economic distortions such as those introduced by taxation and inflation. This paper analyzes the efficiency costs of inflation-tax interactions in open economies. The results indicate that inflation's contribution to deadweight loss is typically far greater in open economies than it is in otherwise-similar closed economies. This much higher deadweight burden of inflation is caused by the international capital flows that accompany inflation in open economies.

Small percentage changes in international capital flows now represent large resource reallocations given two decades of rapid growth of net and gross capital flows in both developed and developing economies. For example, the net capital inflow into the United States grew from an average of $0.1 \%$ of GNP in $1970-72$ to $3.0 \%$ of GNP in 1985-88. Gross capital flows have also expanded rapidly, as indicated by the growth of international loans from a stock of 5\% of GNP in industrial countries in 1973 to $17 \%$ of GNP in $1989 .^{1}$ Similarly, the ratio of the stock of foreign direct investment in the United States to U.S. GNP grew from $1.2 \%$ in 1972 to $7.4 \%$ in $1990 .^{2}$

Inflation rate differences have the potential to reroute much of this international capital since prices inflate at widely different rates around the world. For example, average inflation rates from 1973 to 1989 among OECD countries range from $3.8 \%$ for Germany to $10.6 \%$ for the United Kingdom.

\footnotetext{
${ }^{1}$ Reported in International Monetary Fund (1991).

${ }^{2}$ As reported in Graham and Krugman (1991).
} 
Variation in inflation experiences is even greater in the developing world, with Malaysia averaging $4.6 \%$ and Bolivia $206.7 \%$ during the same period. ${ }^{3}$

The analysis in this paper starts by considering the effects of inflation on saving and investment when governments provide nominal depreciation accounting for tax purposes, firms are able to deduct nominal interest payments, and individual savers are taxed on their nominal interest receipts and capital gains. The model then incorporates open economy considerations, including the taxation of foreign exchange gains and losses, international portfolio capital mobility, and foreign direct investment. The welfare effects of inflation in open domestic and foreign economies are then compared to those in closed economies.

The main finding of this analysis is that inflation in an open economy can generate worldwide reallocations of capital with large associated efficiency consequences. As such, the international dimensions of the effects of inflation are properly considered together with effects that are well known from conventional closed economy analyses. Furthermore, the international effects of inflation-tax interactions suggest that there may be possibilities for efficiency gains through international coordination of monetary and fiscal policies.

Section II of the paper reviews the effects of inflation in closed and open economies with nominal-based tax systems. Section III develops an open economy model incorporating inflation-tax interactions, and uses the model to analyze the effect of domestic inflation on domestic and foreign interest rates, saving, and investment. Section IV translates the real effects of inflation into efficiency terms in order to contrast its welfare consequences in open and closed economies. Sections V and VI generalize the model to include consideration of imperfect international capital mobility and foreign direct investment, respectively. Section VII is the conclusion.

\footnotetext{
${ }^{3}$ Data drawn from Romer (1993) These figures represent average annual changes in log GDP, or GNP deflators, from 1973 to 1989.
} 


\section{Inflation and Taxation in Closed and Open Economies}

Irving Fisher's (1930) hypothesis that nominal interest rates rise by exactly the rate of inflation

$\left(\frac{d r}{d \pi}=1\right.$, in which $r$ is the nominal rate of interest and $\pi$ the inflation rate), was once thought to carry the strong implication that inflation does not influence the size of the capital stock, since real interest rates and therefore real borrowing costs would not change with inflation. Mundell (1963) and Tobin (1965) dispute this conclusion, noting that inflation could raise the capital intensity of an economy through its effect on the demand for liquidity. As nominal interest rates increase, the cost of holding nominal money balances rises, thereby shifting portfolio demand from money to real capital and putting downward pressure on interest rates $\left(\frac{d r}{d \pi}<1\right)$. Subsequent work by Darby (1975) and Feldstein (1976) argues that inflation is likely to have the opposite effect on interest rates $\left(\frac{d r}{d \pi}>1\right)$ in realistic settings in which savers pay taxes on interest receipts and borrowers deduct interest payments.

Darby and Feldstein observe that the tax structure is based on nominal values. In particular, nominal interest payments are deductible and nominal interest receipts are taxed. As a consequence, there are two countervailing effects of inflation. Since lenders are taxed on the pure inflation component of interest rates, higher rates of inflation reduce their after-tax returns. At the same time, borrowers deduct their nominal interest payments and, therefore, higher rates of inflation reduce their after-tax borrowing costs. The net effect of inflation on the real rate of interest depends on the difference between tax rates applicable to savers and borrowers. Darby and Feldstein conclude that nominal rates rise by more than the rate of inflation (the modified Fisher hypothesis, or $\frac{d r}{d \pi}>1$ ) and that inflation may influence the size of the capital stock in a closed economy. Even after incorporating liquidity effects, Feldstein concludes that, for plausible parameter values, inflation is likely to depress the capital stock of a closed economy through its interaction with the tax structure. While these initial models are limited by 
their exclusive consideration of investments that are fully debt financed and tax systems that permit assets to be depreciated at economic rates, the results have been extended to consider alternative means of financing and historic cost depreciation. ${ }^{4}$

Hartman (1979) extends this analysis to open economy settings. In particular, he reconsiders the implication that nominal interest rates rise by more than the rate of inflation. In an open economy with flexible exchange rates and purchasing power parity, Hartman concludes that capital flows will remove any real interest rate differentials caused by interactions between tax systems and inflation. In Hartman's model, inflating countries receive capital inflows that prevent interest rates from rising more than one-for-one with inflation. Howard and Johnson (1982) extend this logic to suggest that the interaction of inflation and taxation could result in either a worldwide reallocation of capital as suggested by Hartman or in a violation of purchasing power parity. More recent investigations focus on ways in which details of tax structure may imply something other than the Hartman result. Sorenson (1986) notes that the differential taxation of exchange gains and losses can generate an outcome in which the inflating country does not receive capital inflows, while $\operatorname{Sinn}(1991)$ shows that inflation in countries with tax systems that use historic cost depreciation may also have effects other than those Hartman posits. Bayoumi and Gagnon (1996) suggest that inflation-taxation interactions can explain observed patterns in capital flows between developed countries.

International evidence of the relationship between nominal interest rates and inflation provides tests of these theories. Hansson and Stuart (1986) survey empirical work suggesting that $\frac{d r}{d \pi}$ is close to, or less than, unity, thereby rejecting the modified Fisher hypothesis. More recent empirical work closely examines certain aspects of this evidence. In particular, Mishkin (1992) analyzes the stochastic trends underlying inflation and interest rates to distinguish between the absence of a short run Fisher effect and the presence of a long-run Fisher effect.

\footnotetext{
${ }^{4}$ See Feldstein, Green and Sheshinski (1978) and Feldstein (1983).
} 


\section{A Model of a Small Open Economy with Taxation}

In order to assess the effect of interactions between inflation and taxation in open economies, it is helpful to review the reasoning that underlies Hartman's (1979) analysis. This framework is then applied to a more general model of saving and investment in a small open economy.

\section{A. The Fisher Effect in a Small Open Economy with Taxation}

Consider the case of a small open economy. In the notation that follows, foreign variables bear asterisks and domestic variables do not. The expected after-tax net return to foreign lenders $\left(r_{n, w}\right)$ investing in the small open economy is:

$$
r_{n, w}=\left(1-\theta^{*}\right) r+\left(1-g^{*}\right) \dot{e}^{*}
$$

in which $\theta^{*}$ is the foreign tax rate on interest receipts from abroad (inclusive of any withholding taxes), $r$ is the home country nominal interest rate, $g^{*}$ is the foreign tax rate on exchange rate-related gains and losses, and $\dot{e}^{*}$ is the anticipated appreciation (in foreign currency) of domestic assets held by foreign lenders. We assume exchange rates to be determined by purchasing power parity (PPP) in the goods market, which implies $\dot{e}^{*}=\pi^{*}-\pi$ (in which $\pi^{*}$ is the foreign inflation rate). ${ }^{5}$ A small open economy must offer foreign lenders an after-tax rate of return equal to returns available elsewhere. ${ }^{6}$ Consequently, capital market equilibrium implies that $\frac{d r_{n, w}}{d \pi}=0$, and differentiating (1) with respect to $\pi$ implies:

\footnotetext{
${ }^{5}$ While this assumption is fairly standard, it is important to note that the literature suggests that PPP is best understood as a long-run phenomenon. See, for example, Abuaf and Jorion (1990), Johnson (1990), Frankel (1991), Wei and Parsley (1995), and Froot, Kim and Rogoff (1995).

${ }^{6}$ Strictly speaking, capital market equilibrium requires that risk-adjusted after-tax returns must be equalized. In the certainty framework used here, risk considerations are absent and capital market equilibrium requires only that aftertax returns be equalized. Explicit consideration of risk would greatly complicate the model without significantly changing its implications. See, for example, Gordon and Varian (1989).
} 


$$
\frac{d r}{d \pi}=\frac{\left(1-g^{*}\right)}{\left(1-\theta^{*}\right)}
$$

in which it is implicit that $\frac{d \pi^{*}}{d \pi}=0$. If foreign tax systems treat exchange rate-related gains and losses in the same way as ordinary income, $g^{*}=\theta^{*}$, and the modified Fisher Effect fails to hold since $\frac{d r}{d \pi}=1 .^{8}$

This mirrors Hartman's (1979) argument and is consistent with much of the empirical work on the relationship between interest rates and inflation. Hartman uses this analysis to infer that capital is drawn toward inflating economies. The following analysis indicates that Hartman's result is a special case of a broader set of possible outcomes in which inflation alters the worldwide allocation of capital.

Why does the modified Fisher Effect fail to appear in an open economy? The result stems from the fact that inflation does not penalize foreign savers in the same way that it does domestic savers. If PPP holds and foreign exchange related gains and losses are taxed in the same way as ordinary income, then foreign lenders are able to deduct foreign exchange losses created by home country inflation. By contrast, domestic savers are unable to deduct from their taxable incomes the real losses they incur as a result of domestic inflation. As a consequence, the modified Fisher Effect fails to appear, and instead interest rates obey the traditional Fisher relationship that $\frac{d r}{d \pi}=1$.

\section{B. The Impact of Domestic Inflation on Worldwide Saving and Investment}

\footnotetext{
${ }^{7}$ In practice, the capital exporting countries whose tax systems are described by Commission of the European Communities (1992, pp. 235-303) generally set $g^{*}=\theta^{*}$. For the issues that arise when these tax rates differ, see Levi (1977) and Wahl (1989).

${ }^{8}$ Note that the condition $\frac{d r}{d \pi}=1$ is also consistent with financial arbitrage for domestic savers. If $g=\theta$ and $\frac{d r}{d \pi}=1$, then domestic inflation reduces equally after-tax returns to investing both at home and abroad.
} 
In order to understand the interaction of inflation and taxation in open economies, it is necessary to specify the way that inflation and taxation affect investment and saving. First consider the role of perfectly anticipated, permanent changes in domestic inflation in altering the incentives to invest domestically and abroad. Inflation affects domestic investment incentives through the use of historic cost depreciation, the taxation of nominal capital gains, and the ability to deduct interest payments. The incentives to invest abroad may also be affected if domestic inflation changes exchange rates or foreign interest rates. In equilibrium, worldwide inflation-induced changes in investment must equal worldwide inflation-induced changes in saving.

Firms invest up to the point at which after-tax marginal returns equal the after-tax marginal cost of funds: ${ }^{9}$

$$
(1-\tau) f^{\prime}-\delta \pi+b \pi=b(1-\tau) r+(1-b) s
$$

in which $\tau$ is the statutory corporate tax rate, $f^{\prime}$ is the marginal product of capital (net of depreciation), $\delta$ reflects the nominal nature of depreciation allowances ( $\delta=0$ implies that the tax system uses economic depreciation), ${ }^{10}$ and $b \pi$ is the effect of inflation in reducing the value of nominal debt. The right side of (3) consists of two terms, the first of which is the after-tax cost of debt, and the second of which is the after-tax cost of equity (in which $s$ is the required payment to shareholders). The firm is assumed to finance a fraction $b$ of marginal investments with debt, and a fraction $(1-b)$ with equity.

\footnotetext{
${ }^{9}$ This notation follows that of Feldstein, Green and Sheshinski (1978).

${ }^{10}$ In this formulation, the tax system provides economic depreciation allowances in the absence of inflation, but after-tax values of these allowances erode at rate $\delta$ with inflation. Actual depreciation schedules tend to be fixed in nominal terms, generating positive short-run values of $\delta$. Over long periods of time, however, governments may adjust depreciation schedules in response to prevailing inflation rates, thereby reducing $\delta$. Auerbach and Hines (1988) offers evidence of such long-run adjustment for the United States in the postwar period.
} 
Differentiating both sides of (3) with respect to inflation, and taking $b$ to be unaffected by inflation, ${ }^{11}$ yields:

$$
(1-\tau) \frac{d f^{\prime}}{d \pi}=(\delta-b)+b(1-\tau) \frac{d r}{d \pi}+(1-b) \frac{d s}{d \pi}
$$

In order to simplify this expression, it is useful to impose that equilibrium net after-tax returns to holding debt and equity are equal:

$$
(1-\theta) s-c \pi=(1-\theta) r-\pi
$$

in which $c$ is the tax rate on inflation-induced capital gains. The left side of (5) consists of after-tax real returns to equity holders, whose share values appreciate at the rate of inflation, but who incur tax obligations at rate $c$ on such appreciation; the right side of (5) is the after-tax real return to holding a one-period bond. ${ }^{12}$ This specification yields a value of $s$ high enough to imply that firms should generally prefer debt to equity finance, since interest payments are deductible and shareholders care only about net returns. Hence, the assumption that $b$ takes a fixed value less than unity is based on considerations, such as bankruptcy, that are omitted from the model.

The shape of the production function determines the extent to which changes in $f^{\prime}$ translate into changes in investment, $K$. This relationship is defined locally as: $d K \equiv-\gamma d f^{\prime}$ (with $\gamma>0$ for concave functions). Similarly, $d K^{*} \equiv-\gamma^{*} d f^{\prime *}$. Differentiating (5) to obtain an expression for $\frac{d s}{d \pi}$, substituting

${ }^{11}$ Optimal choices of $b$ are generaily functions of $\pi$ (and other parameters) rather than fixed values. From the envelope theorem, however, it is appropriate to take $b$ as fixed in calculating the effect of small changes in $\pi$ on the cost of capital.

${ }^{12}$ Equation (5) is an arbitrage condition for domestic savers, implicitly ruling out the possibility that foreigners are marginal investors in domestic equities (and that domestic savers invest marginal funds in foreign equities). The model assumes that international investment takes the form of debt rather than equity contracts. This assumption, which is consistent with available evidence, is discussed further in Sections V and VI. 
the result into (4), and using the result that $\frac{d r}{d \pi}=1$ generates expressions for changes in domestic and foreign investment:

(6) $\quad \frac{d K}{d \pi}=-\gamma\left[\frac{\delta-b}{1-\tau}+b+\frac{(1-b)(c-\theta)}{(1-\tau)(1-\theta)}\right]$

(7) $\quad \frac{d K^{*}}{d \pi}=-\frac{\gamma^{*}}{1-\tau^{*}} \frac{d r^{*}}{d \pi}\left(1-b^{*} \tau^{*}\right)$

Equations (6) and (7) express the inflation-induced changes in capital demand to which it is then possible to match inflation-induced changes in the supply of capital.

Domestic saving is a function of the after-tax real rate of return to domestic savers:

$$
r_{n}=(1-\theta) r-\pi
$$

in which $\theta$ is the personal tax rate on interest receipts. The after-tax real rate of return to foreign savers is:

$$
r_{n}^{*}=\left(1-\theta^{*}\right) r^{*}-\pi^{*}
$$

in which $\theta^{*}$ is the foreign tax rate on interest receipts. Using equations (8) and (9), it is possible to translate changes in inflation into changes in domestic and foreign saving:

(10) $\frac{d S}{d \pi}=-\theta \frac{d S}{d r_{n}}$

$$
\frac{d S^{*}}{d \pi}=\frac{d S^{*}}{d r_{n}^{*}} \frac{d r^{*}}{d \pi}\left(1-\theta^{*}\right)
$$


in which $\frac{d S}{d r_{n}}$ denotes the responsiveness of domestic saving to the after-tax rate of return.It is then possible to use the world capital account identity $\frac{d K}{d \pi}+\frac{d K^{*}}{d \pi} \equiv \frac{d S}{d \pi}+\frac{d S^{*}}{d \pi}$ to determine $\frac{d r^{*}}{d \pi}$ and the worldwide capital reallocations that accompany inflation. ${ }^{13}$

Consider first the case in which domestic and foreign firms finance marginal investments exclusively with debt. Suppose in addition that domestic and foreign personal and corporate tax rates are all equal $\left(\theta=\tau=\tau^{*}=\theta^{*}\right)$ and that depreciation allowances reflect economic depreciation $\left(\delta=\delta^{*}=0\right)$. Define the parameter $\psi$ to equal the ratio of the size of the rest of the world's economy to the size of the home economy. Taking behavioral responses to be proportional to economic size, it follows that $\gamma^{*}=\psi \gamma$ and $\frac{d S^{*}}{d r_{n}{ }^{*}}=\psi \frac{d S}{d r_{n}}$. Equating inflation-induced changes in world capital demand to inflationinduced changes in world capital supply yields:

$$
\frac{d r^{*}}{d \pi}=\frac{1}{\psi}\left(\frac{\tau}{1-\tau}\right)
$$

$$
\frac{d K}{d \pi}=\gamma \frac{\tau}{1-\tau}=-\frac{d K^{*}}{d \pi}
$$

$$
\frac{d S}{d \pi}=-\tau \frac{d S}{d r}=-\frac{d S^{*}}{d \pi}
$$

In this special case of $100 \%$ debt finance, economic depreciation, and all tax rates equal, there is a reallocation of capital but no worldwide reduction in saving and investment. Equation (13) implies that domestic investment increases with inflation and is offset exactly by reduced foreign investment.

\footnotetext{
13 In imposing this identity, the domestic and foreign economies are taken to have single sectors. This formulation abstracts from distortions created by inflation-induced subsidies to certain assets, such as owner-occupied housing.
} 
Similarly, equation (14) indicates that domestic saving is reduced by an amount exactly equal to that by which foreign saving increases. Capital flows to the inflating country from the non-inflating rest of the world, which confirms the basic Hartman (1979) result. Note that the mechanism by which this takes place is one in which domestic inflation raises the foreign nominal interest rate, thereby generating capital exports from the non-inflating rest of the world to the inflating domestic economy. Moreover, the degree to which domestic inflation affects the foreign nominal interest rate is determined by the relative sizes of the domestic and world economies.

It is useful to consider the effect of alternative tax regimes in which depreciation allowances decline in value as inflation rises $(\delta>0)$, those in which tax rates $\operatorname{differ}\left(\theta \neq \theta^{*}\right)$, and cases in which firms are financed at least in part by equity $\left(b<1\right.$ and $\left.b^{*}<1\right)$. In these more general cases, the inflating home economy is described by equations (6) and (10). Note that (10) indicates that domestic saving declines with inflation, since the behavior of domestic savers is influenced by inflation-induced reductions in real after-tax interest rates. Equation (6) suggests that investment can increase with inflation, as in the special case above, but might alternatively fall with inflation if governments offer historic cost depreciation allowances and if marginal investments are financed in part by equity. Equation (6) further implies that $\frac{d^{2} K}{d \pi d b}<0$ and $\frac{d^{2} K}{d \pi d \delta}<0$. These inequalities suggest that both the extent to which firms rely on equity finance and the extent to which inflation erodes the present value of depreciation allowances are responsible for reduced domestic investment at higher rates of inflation.

Equations (7) and (11) present results for the rest of the world. Changes in foreign saving and investment depend on the impact of domestic inflation on foreign interest rates. Equating world inflation-induced supply and demand changes, and imposing $\frac{d r}{d \pi}=1$, produces a modified expression for $\frac{d r^{*}}{d \pi}$ 


$$
\frac{d r^{*}}{d \pi}=\frac{1}{\psi}\left[\frac{\theta \frac{d S}{d r}-\gamma\left(\frac{\delta-b}{1-\tau}+b+\frac{(1-b)(c-\theta)}{(1-\tau)(1-\theta)}\right)}{\frac{d S}{d r}\left(1-\theta^{*}\right)+\frac{\gamma}{1-\tau^{*}}\left(1-b^{*} \tau^{*}\right)}\right]
$$

The sign of $\frac{d r^{*}}{d \pi}$ in (15) is indeterminate but can be easily evaluated in the case in which capital gains are taxed at ordinary income rates $(c=\theta)$. In this case, there are two alternatives, which are summarized in Table 1.

Panel A of Table 1 outlines the results when $\delta<b \tau$. If $\delta<b \tau$, foreign nominal interest rates rise with domestic inflation, foreign investment declines, and foreign savings rise. Inflation reduces domestic saving by lowering the after-tax domestic real interest rate, and increases domestic investment since the benefits of nominal interest deductibility outweigh the tax costs imposed by historic cost depreciation. Consequently, capital flows from the non-inflating rest of the world to the inflating country. The case in which $\delta>b \tau$ is outlined in Panel B and is somewhat more complex. If $\delta>b \tau$, domestic saving and domestic investment decline with inflation since the tax penalties associated with historic cost depreciation exceed the benefits of nominal interest deductibility. Signs of the effect of inflation on foreign nominal interest rates, saving, and investment then depend on more detailed parameter values.

The intuition for the effect of $\tau, \delta$ and $b$ is fairly straightforward. As firms use more debt or pay taxes at higher statutory rates, they benefit from the ability to deduct nominal interest payments - so inflation can stimulate domestic investment. On the other hand, to the degree that the tax system provides something other than economic depreciation allowances, higher rates of inflation raise the cost of capital and discourage investment. In cases in which $c \neq \theta$, the sign of $\frac{d r^{*}}{d \pi}$ depends as well on elasticities of capital supply and demand. 
The magnitude of the effect of domestic inflation on foreign nominal interest rates, expressed in (15), can be illustrated by reference to specific parameter values. Table 2 presents values of $\frac{d r^{*}}{d \pi}$ for a range of home country parameters. For purposes of the calculations presented in Table 2, the home country's economy is taken to represent $9 \%$ of the world economy $(\psi=10) .{ }^{14}$ Foreign parameters are fixed at $b^{*}=0.5, \theta^{*}=0.35, \delta^{*}=0.1$ and $\tau^{*}=0.35$. For the base case in the center of Table 2 , a one percentage point rise in domestic inflation increases the world interest rate by $0.0091 \%$. For the range of home country parameter values considered in Table 2 , the magnitude of the change in the world interest rate accompanying a one percentage point change in domestic inflation ranges from $-0.0158 \%$ to $0.0788 \%$ for a one percentage point change in domestic inflation. ${ }^{15}$

The sensitivity of $\frac{d r^{*}}{d \pi}$ to home country parameters is evident from the pattern within Table 2. For example, the greatest values of $\frac{d r^{*}}{d \pi}$ appear in cases in which corporate tax rates are highest and debt financing most pervasive (inflation thereby generating the largest subsidies to domestic corporate borrowers) and departures from economic depreciation the smallest (inflation thereby imposing the smallest costs of lost real depreciation allowances). By encouraging domestic investment while discouraging domestic saving, inflation is responsible for capital movement from the rest of the world to the inflating country - thereby raising foreign interest rates.

\footnotetext{
${ }^{14}$ The relevant value of $\psi$ depends on country sizes. Using the 1993 share of world output as a measure of the relative size of an economy, $\psi$ is 2.8 for the United States, 4.6 for Japan, 11.7 for Germany, 24.0 for the United Kingdom, and 51.4 for Spain. These measures are based on data from World Bank (1996) and IMF (1997). Measures of $\psi$ based on saving or investment differ from these based on GDP. For example, the values of $\psi$ for the United States and Japan are reversed, at 4.6 and 2.8 , respectively, when $\psi$ is measured on the basis of saving. ${ }^{15}$ Strictly speaking, arbitrage in world capital markets implies that $\frac{d r}{d \pi}=1+\frac{d r^{*}}{d \pi}$. While the approximation that $\frac{d r}{d \pi}=1$ is valid for small, open economies, a precise analysis of inflation in a large, open economy should incorporate this more accurate value. From a practical standpoint, however, this adjustment is unlikely to make a
} 
The cases in which $\frac{d r^{*}}{d \pi}<0$ are those for which inflation reduces domestic saving and domestic investment. If $\frac{d r^{*}}{d \pi}<0$, then domestic investment falls by more than does domestic saving due to erosion of depreciation allowances by inflation and higher costs of investment funds consisting partly of equity. In such cases, capital flows from the domestic economy to the foreign economy, thereby reducing the foreign interest rate, discouraging foreign saving and stimulating foreign investment. The cases in which $\frac{d r^{*}}{d \pi}=0$ consist of situations in which inflation discourages domestic saving and domestic investment equally, thereby requiring no international capital movement in order to maintain capital balances - and, consequently, no change in the foreign interest rate.

In each of these scenarios the underlying logic is the same. First, the ability of foreign lenders to deduct foreign exchange losses forces domestic nominal interest rates to rise one-for one with inflation. Second, the degree to which domestic inflation penalizes domestic saving relative to domestic investment then determines whether capital enters or leaves the inflating country and the extent to which foreign interest rates are affected.

\section{Efficiency Consequences of Inflation in a Small Open Economy}

A consistent analysis of the efficiency consequences of inflation in open economies includes consideration of the deadweight losses generated by inflation together with the implications of inflation for tax revenue. Higher rates of inflation typically, though not uniformly, generate greater tax revenue while exacerbating tax distortions. Since tax revenue is valuable to governments whose alternative sources of revenue are distortionary, the costs of inflation-induced distortions must be weighed against the benefits of greater tax revenue. Additionally, inflation affects economic efficiency and tax revenue 
in two ways: through its interaction with the personal income tax, and through its interaction with the corporate income tax. Consequently, a consistent welfare analysis has four components: $\frac{d D W L_{p}}{d \pi}$, $\frac{d D W L_{c}}{d \pi}, \frac{d R E V_{p}}{d \pi}$, and $\frac{d R E V_{c}}{d \pi}$ where $p$, for personal, denotes the effect of interactions between inflation and personal income taxes, and $c$, for corporate, denotes the effect of interactions between inflation and corporate income taxes.

This section derives expressions for the home and world welfare effects of inflation in open economies, in the process demonstrating that the world efficiency impact of inflation is a function of disparities between domestic and rest of world inflation rates. The revenue impact of inflation in a small open economy is then integrated with deadweight loss considerations to generate overall welfare effects of inflation. The analysis then estimates these effects for realistic cases using a modified version of the methodology employed by Feldstein (1997).

\section{A. Deadweight Loss Due to Inflation-Induced Capital Flows}

The efficiency consequences of inflation-induced international capital movements appear even in the very simplified case analyzed earlier. Specifically, consider again the case in which domestic and foreign firms finance their investments entirely with debt $\left(b=b^{*}=1\right)$, domestic and foreign tax systems provide economic depreciation allowances $\left(\delta=\delta^{*}=0\right)$, and all tax rates are equal $\left(\theta=\tau=\tau^{*}=\theta^{*}\right)$. The effect of inflation on the welfare of a small open economy can be decomposed into the effect of inflation on the allocation of consumption and the effect of inflation on the allocation of investment.

It is useful to consider intertemporal consumption distortions in a two period framework in which individuals save in the first period to finance consumption in the second. In the home country, the aftertax real price of second-period consumption $\left(p_{2}^{a}\right)$, measured in first-period units, is: 
$p_{2}^{a}=\frac{1}{[1+r(1-\theta)-\pi]^{T}}$ where $\mathrm{T}$ is the number of years that elapses between first-period saving and second-period consumption. The before-tax real price of second-period consumption $\left(p_{2}^{b}\right)$, measured in first-period units, is: $p_{2}^{b}=\frac{1}{(1+r-\pi)^{T}}$. The difference between these two prices represents the wedge introduced by the tax system and its interaction with inflation.

The effect of inflation on the efficiency of intertemporal consumption is represented by the interaction of inflation-induced compensated changes in demand for second-period consumption with the tax wedge identified above. As always in analyzing tax-induced deadweight loss, it is important to use compensated rather than uncompensated demand schedules; more specifically, as noted by Feldstein (1978), the compensated demand derivative with which the tax wedge is properly interacted is that for second-period consumption rather than that for saving. Denoting the derivative of compensated demand for second-period consumption by $\frac{d C_{2}}{d p_{2}^{a}}$, the domestic deadweight loss from the consumption reallocation that accompanies a small change in inflation is: $-\frac{d C_{2}}{d p_{2}^{a}} \frac{d p_{2}^{a}}{d \pi}\left(p_{2}^{a}-p_{2}^{b}\right)$. Imposing $\frac{d r}{d \pi}=1$, this deadweight loss can be expressed as:

$$
\frac{d D W L_{p}}{d \pi}=-\frac{d C_{2}}{d p_{2}^{a}} \frac{d p_{2}^{a}}{d \pi}\left(p_{2}^{a}-p_{2}^{b}\right) \cong-T \theta \frac{d C_{2}}{d p_{2}^{a}} p_{2}^{a}\left(p_{2}^{a}-p_{2}^{b}\right)
$$

in which the approximation is valid at low after-tax real interest rates. ${ }^{16}$

${ }^{16}$ Formally, $\frac{d p_{2}^{a}}{d \pi}=\frac{\theta T p_{2}^{a}}{[1+r(1-\theta)-\pi]}$, which approximates $\theta T p_{2}^{a}$ if the after-tax real interest rate is close to zero. 
Interactions between inflation and the corporate income tax also carry welfare implications.

Equations (3) and (5) together imply a value for the marginal product of capital: $f^{\prime}=r-\frac{\pi}{1-\tau}$. Hence

the difference between the marginal product of capital and the pre-tax real rate of return

$\left[f^{\prime}-(r-\pi)\right]$ equals: $-\frac{\tau \pi}{1-\tau}$ in this special case. This negative tax wedge may at first seem paradoxical,

since, in a world without inflation, the effective tax rate is zero if tax systems provide economic

depreciation deductions and marginal investments are financed by debt. The negative effective tax rate

reflects that inflation subsidizes investment by increasing deductible nominal interest payments.

The welfare effect of a change in inflation equals the product of any inflation-induced investment change and the difference between the after-tax and before-tax marginal products of capital.

Accordingly,

$$
\frac{d D W L_{c}}{d \pi}=\frac{\gamma^{2} \pi}{(1-\tau)^{2}}
$$

Adding this to the deadweight loss generated by the personal income tax yields: ${ }^{17}$

$$
\frac{d D W L}{d \pi}=\frac{\gamma^{2} \pi}{(1-\tau)^{2}}-T \theta \frac{d C_{2}}{d p_{2}^{a}} p_{2}^{a}\left(p_{2}^{a}-p_{2}^{b}\right)
$$

which is unambiguously positive. Inflation reduces the efficiency of domestic resource allocation both in consumption, by discouraging second-period consumption that is already penalized by the tax system, and in investment, by encouraging investment that (in the case of pure debt financing and economic depreciation) is already subsidized by the tax system.

\footnotetext{
17 Note that it is appropriate to sum deadweight losses from interactions between inflation and personal taxes and inflation and corporate taxes, because the benchmark real rate of interest, $r-\pi$, is common to both calculations. In a closed economy, such a calculation corresponds to measuring the sizes of two pieces that together compromise the
} 
In this scenario, inflation improves the quality of resource allocation in foreign countries.

Inflation increases foreign saving and reduces foreign investment; since the foreign tax system penalizes saving and subsidizes investment, each of these changes reduces deadweight loss in the foreign country. Specifically, domestic inflation changes foreign deadweight loss by:

$$
\frac{d D W L^{*}}{d \pi}=T \tau p_{2}^{a^{*}}\left(p_{2}^{a^{*}}-p_{2}^{b^{*}}\right) \frac{d C_{2}}{d p_{2}^{a}}-\frac{\gamma \tau^{* 2} \pi^{*}}{\left(1-\tau^{*}\right)^{2}}
$$

Note that this expression is independent of $\psi$, the ratio of the sizes of the rest of the world and the domestic economy. Intuitively, higher values of $\psi$ imply that domestic inflation has a smaller effect on foreign interest rates but that the impact of higher interest rates applies to a larger world economic base, thereby generating an equivalent deadweight loss.

The same terms appear (with opposite signs) in both (18) and (19), thereby suggesting that world welfare might not be affected by inflation. While it is true that domestic inflation reduces deadweight loss in the rest of the world, it does not follow that this reduction is of the same magnitude as the positive impact of inflation on deadweight loss in the home country. This can be illustrated by summing (18) and (19), and imposing equality between the tax and behavioral patterns of the two countries other than their inflation rates (so that, for example, $r^{*}-\pi^{*}=r-\pi$ ):

$$
\begin{aligned}
& \frac{d\left(D W L+D W L^{*}\right)}{d \pi}=\frac{\gamma \tau^{2}}{(1-\tau)^{2}}\left(\pi-\pi^{*}\right)+T \tau \frac{d C_{2}}{d p_{2}^{a}}\left[p_{2}^{a^{*}}\left(p_{2}^{a^{*}}-p_{2}^{b^{*}}\right)-p_{2}^{a}\left(p_{2}^{a}-p_{2}^{b}\right)\right] \\
& \text { Inspection of (20) verifies that } \frac{d\left(D W L+D W L^{*}\right)}{d \pi}=0 \text { when } \pi=\pi^{*}, \text { since the first term on right }
\end{aligned}
$$
side is zero, as is the second term, by virtue of the equalities $p_{2}^{a}=p_{2}^{a^{*}}$ and $p_{2}^{b}=p_{2}^{b^{*}}$. This is a sensible 
result, since the foreign and domestic economies are identical when $\pi=\pi^{\circ}$, making the world equivalent to a large closed economy. Darby (1975) and Feldstein (1976) show that inflation does not reduce the welfare of a closed economy with debt-financed investments and economic depreciation, since inflation does not change after-tax real interest rates and borrowing costs.

In order to characterize the global welfare properties of inflation, it is useful to differentiate both sides of (20) with respect to $\pi$ :

$\frac{d^{2}\left(D W L+D W L^{*}\right)}{d \pi^{2}}=\frac{\gamma^{2}}{(1-\tau)^{2}}+T^{2} \tau^{2} \frac{d C_{2}}{d p_{2}^{a}}\left[\frac{1}{\psi}\left(p_{2}^{a^{*}\left(1+\frac{1}{T}\right)} p_{2}^{b^{*}}+\frac{p_{2}^{a^{*}} p_{2}^{b^{*}}\left(1+\frac{1}{T}\right)}{1-\tau}-2 p_{2}^{a^{*}}\left(2+\frac{1}{T}\right)\right)+\left(p_{2}^{a}\left(1+\frac{1}{T}\right) p_{2}^{b}-2 p_{2}^{a}\left(2+\frac{1}{T}\right)\right)\right]$

The first term on the right side of (21) is positive, and since $\frac{d C_{2}}{d p_{2}^{a}}<0$, the second term is also positive if the bracketed expression is less than zero. In evaluating the sign of this bracketed expression, it is useful to note that $p_{2}^{a}>p_{2}^{b}, p_{2}^{a^{*}}>p_{2}^{b^{*}}$, and if $\pi>\pi^{*}, p_{2}^{a}>p_{2}^{a^{*}}$ while $p_{2}^{b}>p_{2}^{b^{*}}$. As a result, an upper bound of the absolute value of the expression in brackets can be obtained by evaluating the expression if $p_{2}^{u}=p_{2}^{h}=p_{2}^{a^{*}}=p_{2}^{h^{*}}:$

$$
\frac{d^{2}\left(D W L+D W L^{*}\right)}{d \pi^{2}} \geq \frac{\gamma \tau^{2}}{(1-\tau)^{2}}+T^{2} \tau^{2} \frac{d C_{2}}{d p_{2}^{a}} p_{2}^{a}\left(2+\frac{1}{T}\right)\left[\frac{1}{\psi}\left(\frac{1}{1-\tau}-1\right)-1\right]
$$

The term in brackets on the right side of (22) is less than zero as long as $\tau<\frac{\psi}{1+\psi}$. Since the rest of the world is taken to be large relative to the inflating economy, this condition is equivalent to the realistic 
case of tax rates less than $100 \%$. Consequently, both terms on the right side of (22) are positive, and

$$
\frac{d^{2}\left(D W L+D W L^{*}\right)}{d \pi^{2}}>0
$$

Figure 1 depicts the relationship between deadweight loss and inflation differences. The $\frac{d\left(D W L+D W L^{*}\right)}{d \pi}$ schedule is upward-sloping and takes a value of zero at $\pi=\pi^{*}$. Accordingly, as is evident from the figure, $\frac{d\left(D W L+D W L^{*}\right)}{d \pi}$ takes the same sign as $\left(\pi-\pi^{*}\right)$. The deadweight loss function is also nonlinear in $\pi$, generally taking a convex form (as pictured).

Equation (20) indicates that the aggregate welfare cost of domestic inflation depends on existing disparities between national inflation rates. In the scenario under consideration, greater domestic inflation improves world welfare if the rest of the world has a higher rate of inflation. ${ }^{18}$ Conversely, if the domestic inflation rate exceeds the world inflation rate, higher domestic inflation reduces world welfare. The international reallocations that accompany inflation stem from the fact that foreign lenders deduct exchange losses when calculating their taxable incomes. Domestic inflation increases nominal interest rates by the same amount that it reduces expected exchange gains of foreign lenders. Consequently, domestic inflation does not generate any additional tax liabilities for foreign lenders. But domestic lenders, who are taxed on their nominal interest receipts without any adjustments for inflation, face lower after-tax real interest rates and therefore save less as inflation rises. Domestic corporations deduct nominal interest payments and therefore invest more at higher rates of inflation. As a result, capital flows from noninflating countries to inflating countries.

\footnotetext{
${ }^{18}$ It is worth emphasizing that this result depends on the values of relevant parameters. There exist scenarios in which higher domestic inflation reduces world welfare, even though world inflation rates exceed the domestic rate.
} 
These international capital reallocations are costly because they imply that too little saving and too much investing take place in inflating countries relative to noninflating countries. It is noteworthy that the nonzero deadweight loss derivative in (20) appears in a scenario - one in which firms finance their marginal investments with debt and governments provide depreciation allowances that do not erode with inflation - in which inflation would not generate deadweight loss if the economy were closed. All of the deadweight loss described in (20) comes from international capital movements and associated effects.

In the more general case in which governments provide historic cost depreciation and investments are financed at least in part by equity, the expression for the component of deadweight loss generated by personal taxation is unchanged from (16). The expression for the component of deadweight loss generated by corporate taxation does, however, change, as the expressions for the preexisting tax wedge and inflation-induced change in domestic investment become somewhat more complicated. Taking $c=\theta$ for simplicity, the domestic deadweight loss due to interactions between inflation and corporate taxation systems is:

$$
\frac{d D W L_{c}}{d \pi}=\frac{\gamma}{(1-\tau)^{2}}[(\delta-\tau b)(r \tau(1-b)+\pi(\delta-\tau))]
$$

This expression can be understood as the product of the investment response, represented by $\frac{\gamma(\delta-b \tau)}{1-\tau}$, and the preexisting distortion, represented by $\frac{[(r \tau(1-b)+\pi(\delta-\tau))]}{1-\tau}$. Relative values of $\delta$ and $b \tau$ dictate whether inflation encourages or discourages domestic investment. The sign of the preexisting distortion indicates whether effective tax rates are positive or negative. Their product determines whether deadweight losses are positive or negative. For example, if the effective tax rate is positive and inflation discourages domestic investment, (23) is positive. If the effective tax rate is negative and inflation encourages domestic investment, (23) is again positive. 
Expressions for foreign deadweight loss in the general case are slightly more complicated than that in (19). Deadweight losses generated by interactions between inflation and foreign corporate and personal taxes are:

$$
\frac{d D W L_{p}^{*}}{d \pi}=T\left(\frac{d r^{*}}{d \pi}\left(1-\theta^{*}\right)\right) p_{2}^{a^{*}}\left(p_{2}^{a^{*}}-p_{2}^{b^{*}}\right) \frac{d C_{2}^{*}}{d p_{2}^{a^{*}}}
$$

$$
\frac{d D W L_{c}^{*}}{d \pi}=\frac{\gamma^{*}}{\left(1-\tau^{*}\right)^{2}}\left[r^{*} \tau^{*}\left(1-b^{*}\right)+\pi^{*}\left(\delta^{*}-\tau^{*}\right)\left[\frac{d r^{*}}{d \pi}\left(1-b^{*} \tau^{*}\right)\right]\right.
$$

where $\frac{d r^{*}}{d \pi}$ is as represented in (15).

\section{B. The Revenue Impact of Inflation}

Inflation rates influence tax collections, which in turn have welfare implications since alternative sources of tax revenue are generally distortionary. The impact of inflation on the present value of personal income tax revenue is:

$$
\frac{d R E V_{p}}{d \pi}=\frac{d p_{2}^{a}}{d \pi} C_{2}+\left(p_{2}^{a}-p_{2}^{b}\right) \frac{d C_{2}}{d p_{2}^{a}} \frac{d p_{2}^{a}}{d \pi}
$$

The first term in (26) reflects revenue obtained by changing the price of retirement consumption, while the second term reflects the revenue effect of changes in retirement consumption, holding its price constant. In general, the sign of (26) is indeterminate. The impact of inflation on corporate tax revenue is similarly:

$$
\frac{d R E V_{c}}{d \pi}=\frac{d f^{\prime}}{d \pi} K-\left[f^{\prime}-(r-\pi)\right] \frac{d f^{\prime}}{d \pi} \gamma
$$


In order to unify the analysis of deadweight loss and revenue effects of inflation, it is necessary to assign a shadow value to government revenue equal to $(1+\lambda)$, in which a value of $\lambda>0$ reflects the deadweight loss that accompanies alternative sources of tax revenue. Accordingly, the overall effect of inflation on social welfare is:

$$
\frac{d S W}{d \pi}=\lambda \frac{d R E V}{d \pi}-\frac{d D W L}{d \pi}
$$

where $S W$ denotes social welfare.

\section{Estimation of the Welfare Impact of Inflation}

In order to estimate magnitudes of (28) it is helpful to use the empirical framework sketched by Feldstein (1997). Interactions between inflation and the personal income tax generate deadweight loss given by:

$$
\frac{d D W L_{p}}{d \pi}=-\left(p_{2}^{a}-p_{2}^{b}\right) \frac{d C_{2}}{d p_{2}^{a}} \frac{d p_{2}^{a}}{d \pi}
$$

where $\frac{d p_{2}^{a}}{d \pi}=T\left[1-\frac{d r}{d \pi}(1-\theta)\right] p_{2}^{a} \frac{1}{1+r(1-\theta)-\pi}$ and $T$ is the number of years in a period. Equation (29) can be transformed into a direct analog of Feldstein's equation (4):

$$
\frac{d D W L_{p}}{d \pi}=\left(p_{2}^{a}-p_{2}^{b}\right)\left(\frac{1}{p_{2}^{a}}\right)^{2} \frac{d p_{2}^{a}}{d \pi} S_{2}\left(1-\eta_{S_{n}}-\sigma\right)
$$

in which $S_{2}$ is saving in preretirement years, $\eta_{S p}$ is the uncompensated elasticity of saving with respect to the price of retirement consumption, and $\sigma$ is the propensity to save out of exogenous income. Further 
manipulation yields an expression that is easily calibrated. Taking $\eta_{S p}=0, \sigma=0.12$, and

$S_{2}=0.09 G D P,{ }^{19}(30)$ becomes:

$$
\frac{d D W L_{p}}{d \pi}=\left(p_{2}^{a}-p_{2}^{b}\right) \frac{1}{p_{2}^{a^{2}}} \frac{d p_{2}^{a}}{d \pi}(.0792 G D P)
$$

In order to evaluate this expression, it is useful to assume that thirty years elapse between periods, and to consider the case that $r=0.07, \pi=0.02$, and $\theta=0.35$ in a small open economy in which $\frac{d r}{d \pi}=1$. Under these assumptions, $\frac{d D W L_{p}}{d \pi}=0.4115 G D P$ which is similar to estimates reported by Feldstein (1997). ${ }^{20}$

A similar procedure can be used to estimate the revenue consequences of domestic inflation. Equation (26) can be transformed to yield:

$$
\frac{d R E V_{p}}{d \pi}=\frac{d p_{2}^{a}}{d \pi} \frac{1}{p_{2}^{a}} S_{2}\left[1-\left(p_{2}^{a}-p_{2}^{b}\right) \frac{1}{p_{2}^{a}}\left(1-\eta_{S_{p}}-\sigma\right)\right]
$$

Assuming the uncompensated elasticity of saving with respect to the after-tax interest rate to be zero, and taking $r=0.07, \pi=0.02$, and $\theta=0.35$, it follows that $\frac{d R E V_{p}}{d \pi}=0.5100 G D P$. With $\lambda=0.4$, the overall welfare impact of interactions between inflation and personal income taxes is $\frac{d S W_{p}}{d \pi}=-0.2075 G D P .^{21}$

\footnotetext{
${ }^{19}$ This value of preretirement savings is derived by linking preretirement saving with national income account measures of personal saving as in Feldstein (1997).

${ }^{20}$ This estimate implies that a $2 \%$ reduction in inflation produces an efficiency gain of $0.823 \%$ GDP per year; Feldstein estimates the gain to be $0.730 \%$ GDP per year.

${ }_{21}$ There is considerable dispute over the correct value of $\lambda$ for the U.S. economy. Ballard, Shoven and Whalley (1985) estimate values of $\lambda$ between 0.17 and 0.56 , on the basis of which (in addition to other calculations) many authors use $\lambda=0.40$ as a baseline for deadweight loss calculations. For considerably higher estimates of $\lambda$, see Feldstein (1995).

It is possible to calculate the implied values of $\lambda$ for the model by comparing marginal tax revenue and marginal deadweight losses as tax rates vary. At baseline parameter values, the model implies $\lambda=0.22$ if corporate taxes are
} 
The distinguishing difference between inflation-induced deadweight losses in open and closed economies lies in values of $\frac{d r}{d \pi}$, and, consequently, $\frac{d p_{2}^{a}}{d \pi}$. In an open economy, $\frac{d r}{d \pi}=1$ due to arbitrage in the world capital market, while in a closed economy, $\frac{d r}{d \pi}$ varies with the underlying parameters of the economy. The Appendix presents an analogous closed economy model for which it derives $\frac{d r}{d \pi}$. Table 3 illustrates the difference between closed and open economies by presenting estimates of $\frac{d r}{d \pi}$ in closed economies and using these values to estimate the components of the welfare effect of interactions between inflation and personal income taxes in closed economies: $\left(\frac{d D W L_{p}}{d \pi}\right)^{\text {clased }}$ and $\left(\frac{d R E V_{p}}{d \pi}\right)^{\text {clased }}$. These values are then used to construct ratios of welfare losses from personal income taxes in open and closed economies.

The first line of Table 3 evaluates the Feldstein-Darby case of $100 \%$ debt financing and economic depreciation allowances. The closed economy is not distorted by inflation, since the nominal interest rate rises sufficiently to generate no change in the after-tax price of retirement consumption. Since inflation is responsible for deadweight loss in small open economies, the ratio of deadweight losses in open and closed economies, provided in column 7, is infinite. Realistic alternative scenarios with some non-debt financing and departures from economic depreciation offer additional information. The ratio of deadweight losses in open and closed economies varies directly with values of $\left(\frac{d r}{d \pi}\right)^{\text {clased }}$. Intuitively, the ratio of deadweight losses in open and closed economies equals unity when $\left(\frac{d r}{d \pi}\right)^{\text {closed }}=1$. If $\left(\frac{d r}{d \pi}\right)^{\text {closed }}>1$, then $\left(\frac{d p_{2}^{a}}{d \pi}\right)^{\text {closed }}<\left(\frac{d p_{2}^{a}}{d \pi}\right)^{\text {open }}$ which implies that the efficiency costs of the marginal source of funds and $\lambda=0.81$ if personal taxes are the marginal source of funds. Hence, 
interactions between inflation and personal income taxes are more modest in closed economies than in open economies. Alternatively, if $\left(\frac{d r}{d \pi}\right)^{\text {closed }}<1$, then $\left(\frac{d p_{2}^{a}}{d \pi}\right)^{\text {closed }}>\left(\frac{d p_{2}^{a}}{d \pi}\right)^{\text {open }}$ and the efficiency costs of inflation-personal tax interactions in closed economies exceed those in open economies. In a reference case in which $b=0.5$ and $\delta=0.1$, open economies are characterized by $20 \%$ greater deadweight losses from interactions with personal taxation than are closed economies. ${ }^{22}$

Inflation is responsible for the following deadweight losses through its interaction with corporate taxes:

$$
\frac{d D W L_{c}}{d \pi}=\left[f^{\prime}-(r-\pi)\right] \frac{d f^{\prime}}{d \pi} \gamma
$$

The associated revenue consequences are:

$$
\frac{d R E V_{c}}{d \pi}=\frac{d f^{\prime}}{d \pi} K-\left[f^{\prime}-(r-\pi)\right] \frac{d f^{\prime}}{d \pi} \gamma
$$

where $\frac{d f^{\prime}}{d \pi}=\frac{1}{1-\tau}\left[\frac{d r}{d \pi}(1-b \tau)-(1-\delta)\right]$. In order to calibrate $\gamma$, we assume that the economy has a Cobb-Douglas production function and corresponding unit elasticity of capital demand. In order to make the results comparable with the analysis of intertemporal consumption distortions, we further assume the capital stock to be twice the size of GDP.

Distinctions between open and closed economies are reflected in values of $\frac{d r}{d \pi}$ and $\frac{d f^{\prime}}{d \pi}$. In a closed economy with zero uncompensated savings elasticity, inflation does not affect the size of the

$\lambda=0.40$ appears to be a reasonable baseline case.

${ }^{22}$ Auerbach (1978) calculates a value of $\delta=0.23$ for the U.S. tax system in the 1970s. Subsequent U.S. tax changes have reduced the inflation sensitivity of the present value of depreciation allowances, making $\lambda=0.10$ a reasonable base case. 
capital stock. However, in calculating the welfare consequences of inflation, it is important to incorporate that, if individuals are compensated for real income changes due to inflation, the size of the capital stock will change. Accordingly, deadweight loss calculations must be performed in a setting in which inflation affects the size of the capital stock in a closed economy - even though the uncompensated saving elasticity is zero. In open economies, the interaction between corporate taxes and inflation generate further distortions through international capital flows. Table 4 provides estimates of (33) and (34) under different scenarios in a manner comparable to the presentation in Table 3.

The first column of Table 4 indicates the responsiveness of the marginal product of capital to inflation and, as such, reflects whether investment flows into or out of the inflating economy. The entries correspond to those presented in Table 1, in that their signs depend on the relative magnitude of $\delta$ and the product of $b$ and $\tau$. The second column indicates the size of the existing tax wedge, $\left[f^{\prime}-(r-\pi)\right]$. Signs of entries in columns 1 and 2 of Table 4 determine signs of the impact of inflation on investment efficiency. Common signs indicate either that the effective tax wedge is negative and inflation is associated with greater investment or that the effective tax wedge is positive and inflation is associated with reduced investment. In either of these cases, higher rates of inflation are associated with greater deadweight loss. Given the small size of inflation-induced deadweight loss in the closed economy, the ratio of deadweight losses from corporate taxes in open and closed economies approximates $\pm \infty$. In the base case of $b=0.5$ and $\delta=0.1$, the signs of the two components of deadweight loss differ (there is a positive effective tax wedge while higher inflation rates increase investment) so higher rates of inflation reduce deadweight loss.

Table 5 summarizes the results of Tables 3 and 4 . Note that the ratios in column 5 typically exceed unity and that the deadweight losses due to taxes in open economies range from 0.2006 GDP to 1.0522 GDP. These values suggest that the efficiency gain from reducing inflation by $2 \%$ is bounded by $0.40 \%$ GDP per year and $2.10 \%$ GDP per year. In the base case of $b=0.5$ and $\delta=0.1$, the inflating 
economy experiences $40 \%$ greater inflation-induced welfare loss when open relative to when it is closed to the rest of the world. In this context, it is noteworthy that the closed economy deadweight losses from inflation, with the exception of the case of all-debt financing and economic depreciation, are not trivial.

Table 6 outlines the relevant welfare considerations for the rest of the world. The first three columns detail the welfare impact of distortions to intertemporal consumption choices. These results are directly linked to the results on $\frac{d r^{*}}{d \pi}$ presented in the second column of Table $2 .^{23}$ Note that when the foreign nominal interest rates rises with domestic inflation $\left(\frac{d r^{*}}{d \pi}>0\right)$, the foreign after-tax price of consumption declines $\left(\frac{d p_{2}^{a^{*}}}{d \pi}<0\right)$ and, consequently, foreign welfare improves. Foreign parameters match the base case of the inflating economy $\left(b^{*}=0.5, \tau^{*}=0.35, \delta^{*}=0.1\right.$, and $\left.\theta^{*}=0.35\right)$. At these parameter values, there exists a positive investment tax wedge, and signs of the figures in column four correspond to the direction of investment flows in response to domestic inflation. Column 7 aggregates the world welfare consequences of inflation in open and closed economies. In the base case, the impact of inflation on world welfare is $49 \%$ greater when the inflating economy is open than when it is closed.

\section{Imperfect Capital Mobility}

The validity of the assumption that capital is perfectly mobile internationally is frequently questioned on the basis of the persistent correlation between savings and investment for a variety of

\footnotetext{
23 Note that the values of $\frac{d r^{*}}{d \pi}$ presented in Table 2 are based on calculations using uncompensated saving elasticities, while the values of $\frac{d r^{*}}{d \pi}$ used in the welfare analysis are based on calculations using compensated savings elasticities. Implied values of $\frac{d r^{*}}{d \pi}$ only differ slightly between these two cases.
} 
countries and the widespread home bias in domestic portfolios. ${ }^{24}$ The economic significance of imperfect capital mobility is a matter of some dispute. In the present context, it suggests that capital might not flow in sufficient volume to inflating countries in order to maintain local before-tax real interest rates at world levels. Such a failure to equate real interest rates implies a failure of arbitrage that is consistent with profit maximizing behavior only if lenders incur some costs associated with international capital flows. In order to examine the implications of imperfect intemational capital mobility, this section analyzes a model in which such costs are present.

The most convenient way in which to introduce the model of imperfect capital mobility is to specify the reaction of domestic interest rates to inflation. Specifically, suppose that:

$$
\frac{d r}{d \pi}=1+\mu
$$

in which $\mu$ is a free parameter that is zero if capital is perfectly mobile internationally, and is nonzero if capital mobility is limited by some kind of transaction cost. The value of $\mu$ takes the same sign as the value of $\left(\frac{d r}{d \pi}-1\right)$ in an otherwise-equivalent closed economy. Of course, $\mu$ is not a choice variable but instead a function of transaction costs as well as the supply and demand conditions for world capital. For the moment, it is useful to take $\mu$ to be a given parameter that represents costs associated with information-gathering or a reduction in return attributable to gains from diversification. ${ }^{25}$

\footnotetext{
${ }^{24}$ On the saving-investment correlation, see Feldstein and Horioka (1980) and Frankel (1991). French and Poterba (1991), Tesar and Warner (1994, 1995), and Cooper and Kaplanis (1994) provide evidence of the home-bias phenomenon. These studies assess possible causes for limited international diversification - such as high transactions costs or the desire to hedge against deviations from PPP - and reject these hypotheses.

${ }^{25}$ Note that this specification of the transaction costs associated with international capital mobility does not parallel the "iceberg" models of international trade but rather posits that transaction costs are current instead of capital costs. Furthermore, the costs are assumed to be tax deductible - which is sensible if, for example, the costs take the form of payments to market analysts or reduced risk-adjusted returns.
} 
The effect of domestic inflation on domestic saving is then no longer represented by (10), instead becoming:

$$
\frac{d S}{d \pi}=\frac{d S}{d r}[(1-\theta)(1+\mu)-1]=\frac{d S}{d r}(-\theta+\mu(1-\theta))
$$

In a similar manner, the effect of domestic inflation on domestic investment becomes a function of $\mu$.

Combining (4), (5), and (35) yields:

$$
\frac{d K}{d \pi}=-\gamma\left[\frac{\delta-b}{1-\tau}+b-\frac{(1-b)(c-\theta)}{(1-\tau)(1-\theta)}+\frac{\mu(1-\tau b)}{1-\tau}\right]
$$

Equilibrium in the capital market requires equality of world inflation-induced capital supply and capital demand changes, which in turn requires that (15) be modified in the presence of imperfect capital mobility to:

$$
\frac{d r^{*}}{d \pi}=\frac{1}{\psi}\left[\frac{(\theta-\mu(1-\theta)) \frac{d S}{d r}-\gamma\left(\frac{\delta-b}{1-\tau}+b+\frac{(1-b)(c-\theta)}{(1-\tau)(1-\theta)}+\frac{\mu(1-\tau b)}{1-\tau}\right)}{\frac{d S}{d r}\left(1-\theta^{*}\right)+\frac{\gamma}{1-\tau^{*}}\left(1-b^{*} \tau^{*}\right)}\right]
$$

This value of $\frac{d r^{*}}{d \pi}$ in turn determines $\frac{d K^{*}}{d \pi}, \frac{d S^{*}}{d \pi}$, and the welfare effects associated with the behavioral responses.

Comparing (36) with (10), (37) with (6), and (38) with (15), it is clear that the introduction of imperfect capital mobility limits the reduction in domestic saving and the change in domestic investment associated with inflation. Furthermore, imperfect capital mobility reduces the effect of domestic inflation on the world interest rate. This analysis of capital immobility is comparable with the closed economy analysis of Feldstein (1976). In the context of economic depreciation, equal tax rates, and all- 
debt financing ( $\tau=\theta, b=1$ and $\delta=0$ ), $\mu$ is bounded between 0 (for perfectly mobile capital markets) and $\frac{\tau}{1-\tau}$ (for closed economies). When $\mu=\frac{\tau}{1-\tau}$, the economy is effectively closed, and, as a result, domestic saving and investment are unaffected by inflation.

Imperfect international capital mobility introduces two other potentially important differences to the welfare analysis of inflation. The first is that inflation may have a first-order effect on the terms at which a country can borrow, and consequently may be responsible for income redistribution between foreigners and domestic residents. The second is that the transaction costs associated with international capital mobility must be incorporated into the welfare analysis since inflation that reallocates capital internationally is responsible for these additional costs.

The real rate of interest paid on borrowing by the home country is $(r-\pi)$, so the effect of inflation on the home country's real borrowing cost is $\left(\frac{d r}{d \pi}-1\right)=\mu$. As the home country borrows net capital equal to $(K-S)$ from the rest of the world, a small change in domestic inflation is responsible for a wealth transfer from home country residents of an amount equal to: $\mu(K-S)$. Foreign lenders do not receive all of this amount, however, since the return on their inframarginal lending rises by $\frac{d r^{*}}{d \pi}(K-S)$. $\mu$ differs from $\frac{d r^{*}}{d \pi}$ due to the deadweight losses that accompany saving and investment distortions as well as the adjustment costs incurred as a result of inflation-induced changes in net international lending.

Putting these pieces together, the impact of inflation on domestic welfare is in part given by (16) and (23), properly modified to incorporate the behavioral effects described by (36) and (37). In addition, if the home country is a capital importer, domestic residents lose $\mu(K-S)$ with every unit change in inflation. Hence the effect of inflation on welfare in the home country is given by: 
(39) $\left.\frac{d D W L}{d \pi}=\frac{\gamma}{(1-\tau)^{2}}[\delta-\tau b+\mu(1-\tau b)] r \tau(1-b)+\pi(\delta-\tau)\right]-T[1-(1+\mu)(1-\theta)] p_{2}^{a} \frac{d C_{2}}{d p_{2}^{a}}\left(p_{2}^{a}-p_{2}^{b}\right)+\mu(K-S)$

in which the last component, $\mu(K-S)$, represents a wealth transfer and not inefficiency.

In order to examine the impact of imperfect capital mobility on the welfare of the rest of the world, it is necessary to specify the costs associated with imperfect capital mobility. The equilibrium condition is that small changes in inflation in a small open economy cannot affect net-of-adjustment-cost real rates of return available to foreign lenders. Hence, it must be the case that marginal adjustment costs equal the difference between real rates of return at home and abroad, $\left(r^{*}-\pi^{*}\right)-(r-\pi)$, and the change in adjustment costs for which a small change in inflation is responsible equals:

$$
\left(\frac{d K}{d \pi}-\frac{d S}{d \pi}\right)\left[(r-\pi)-\left(r^{*}-\pi^{*}\right)\right]
$$

The reduction in foreign welfare that accompanies a domestic inflation is in part given by (24) and (25), properly modified to incorporate (38). In addition, foreign residents gain an amount after adjustment costs equal to:

$$
\mu(K-S)-\left(\frac{d K}{d \pi}-\frac{d S}{d \pi}\right)\left[(r-\pi)-\left(r^{*}-\pi^{*}\right)\right]
$$

Additional restrictions on the form of adjustment costs permit (41) to be further simplified. Consider, for example, the case of quadratic adjustment costs, in which $\mu=\zeta\left(\pi-\pi^{*}\right)$. This specification implies that $\left[(r-\pi)-\left(r^{*}-\pi^{*}\right)\right]=\frac{\mu}{2}\left(\pi-\pi^{*}\right)$, so the inflation-induced income transfer to foreigners, net of adjustment costs, is 


$$
\mu\left[(K-S)-\left(\frac{d K}{d \pi}-\frac{d S}{d \pi}\right) \frac{\left(\pi-\pi^{*}\right)}{2}\right]
$$

For small values of $\mu$ and $\pi, \frac{d K}{d \pi}$ and $\frac{d S}{d \pi}$ are unaffected by $\pi$, and $(K-S) \cong\left(\frac{d K}{d \pi}-\frac{d S}{d \pi}\right)\left(\pi-\pi^{*}\right)$.

Imposing this approximation implies that half of the income transfer to foreigners is lost in transaction costs, and the net welfare gain for foreign residents from domestic inflation is given by:

$$
\frac{d D W L^{*}}{d \pi}=\tau\left(\frac{d r^{*}}{d \pi}\left(1-\theta^{*}\right)\right) p_{2}^{a^{*}}\left(p_{2}^{a^{*}}-p_{2}^{b^{*}}\right) \frac{d C_{2}^{*}}{d p_{2}^{a^{*}}}+\frac{\gamma^{*}}{\left(1-\tau^{*}\right)}\left[r^{*} \tau^{*}\left(1-b^{*}\right)+\pi^{*}\left(\delta^{*}-\tau^{*}\right)\right]\left[\frac{d r^{*}}{d \pi}\left(1-b^{*} \tau^{*}\right)\right]-\frac{\mu}{2}(K-S)
$$

in which the last piece $\left[\frac{\mu}{2}(K-S)\right]$ is the income transfer to foreigners, and $\frac{d r^{*}}{d \pi}$ is given by (38).

Imperfect capital mobility has an indeterminate effect on world welfare. There are important scenarios in which imperfect capital mobility reduces inflation-induced capital reallocations and associated deadweight losses. At the same time, however, capital immobility reflects transactions costs for which inflation may be partly responsible. As a result, the net welfare effects of inflation-tax interactions with imperfect capital mobility are case-specific.

\section{Foreign Direct Investment}

The analysis to this point considers investments that are financed through a combination of equity held by domestic residents and debt that may be held either by domestic or foreign residents. Consequently, the only form in which international investment is undertaken is by cross-border portfolio lending. There are at least two other important possibilities. The first is cross-border individual investing in equities. International investment seldom takes this form, and, as Gordon (1986) notes, the effect of inflation on equilibrium capital flows with cross-border equity holdings is unlikely to differ significantly from the effect of inflation when international capital flows are limited to portfolio 
investments. Consequently, little realism is lost by abstracting from the ability of investors to hold foreign equities.

The second important alternative possibility is that some foreign investments are undertaken by domestic firms with controlling interests in their foreign operations. Foreign direct investment of this type may have different financial characteristics than local operations in foreign countries, and typically receives different tax treatment from home countries. ${ }^{26}$ It is, however, important to note that foreign direct investments almost uniformly receive the same tax treatment from host countries as do local firms. Consequently, the significance of foreign direct investment to the effect of inflation on international capital flows and associated welfare costs is that its financing may differ from the financing arrangements of local firms. Given the small size of foreign direct investment relative to portfolio capital flows, and the modest difference between its incentives and those of portfolio investors, treating all cross-border investment as portfolio flows offers a reasonable approximation to a complete treatment of cross-border investment.

\section{Conclusion}

The results reported in this paper indicate that there are important efficiency implications of the international dimensions of inflation-tax interactions. In particular, inflation in one country can generate sizable international capital flows with attendant changes in domestic and foreign welfare. The central mechanism for these flows is the ability of foreign savers to convert the inflation component of their nominal interest receipts into a foreign exchange loss, while domestic savers do not have the ability to do so. As a consequence, inflation discourages domestic saving and encourages domestic investment by reducing the after-tax rate of return, and foreign saving must finance the resulting difference. ${ }^{27}$ The

\footnotetext{
26 See Hines (1996) for a review of the practice and effect of taxing foreign direct investment.

27 Desai (1997) offers evidence that this open economy result may explain the empirical regularity, noted by Romer (1993), that more open economies have lower inflation rates.
} 
translation of these capital flows into efficiency terms indicates that inflation-tax interactions yield distortions of possibly much greater magnitude in open economies than they do in closed economies. In part, this difference reflects the greater mobility of capital in an open economy and the larger deadweight loss that therefore accompanies any given tax-induced distortion.

This analysis of inflation-tax interactions in open economies departs from the earlier work of Hartman (1979) in three ways. The first is to note that capital need not flow to inflating countries, since the direction of capital flow depends on the details of an inflating country's tax system. The second is to stress the related idea that, as a consequence of these flows, domestic inflation influences world interest rates. Even though the size of a small economy's effect on world interest rates is barely perceptible, the resulting welfare effect may be quite large, since the world interest rate influences an extremely large base of capital. The third departure is to measure the impact of inflation-induced capital flows on economic welfare at home and in the rest of the world.

The paper does not analyze certain consequences of inflation. The analysis does not include estimates of the lump-sum income redistributions that accompany unanticipated changes in inflation, nor does it include the effects of possible disruptions to import and export markets that may react sluggishly to real exchange rate changes. The one-sector model does not capture distortions created by subsidizing specific assets, such as owner-occupied housing. In addition, the analysis considers only permanent changes in inflation rates. Transitory inflation changes current costs of holding assets without necessarily changing future costs, thereby generating deadweight losses that differ from those analyzed in the paper. The analysis does not incorporate any of the costs associated with the credibility of future monetary policy for which inflation may be responsible, and abstracts entirely from the macroeconomic effects of inflation.

In spite of these omissions, the results in the paper identify an important possible motivation for monetary and fiscal policy coordination between countries. The welfare consequences of domestic 
inflation are greatly amplified if the home country's inflation rate exceeds world levels, and are reduced as inflation rates are equated across countries. It may not, however, be in the perceived interest of all countries to harmonize their inflation rates, since deviations from a common inflation rate may improve the welfare of deviating countries at the expense of others. As an empirical matter, countries typically select different inflation targets. The point of this paper is to explore the welfare consequences of such heterogeneous inflation experiences in open economies. The results indicate that the effects of inflation in open economies may be far more dramatic, both for home countries and for the world, than are the equivalent welfare effects of inflation in closed economies. 


\section{Appendix}

The purpose of this appendix is to identify the closed economy model that is the basis of the welfare comparisons presented in Section IV. Using the same notation introduced earlier in the paper, capital market equilibrium in closed economies implies that any inflation-induced saving changes are matched exactly by inflation-induced investment changes:

(A1) $\frac{d S}{d \pi}=\frac{d K}{d \pi}$

which in turn implies:

$$
\frac{d S}{d \pi}\left[\frac{d r}{d \pi}(1-\theta)-1\right]=-\gamma\left\{\frac{d r}{d \pi} \frac{1-b \tau}{1-\tau}-\left[\frac{(1-b)(1-c)}{(1-\tau)(1-\theta)}-\frac{\delta-b}{1-\tau}\right]\right\}
$$

This equality implies an effect of inflation on nominal interest rates in closed economies:

$$
\left(\frac{d r}{d \pi}\right)^{\text {closed }}=\frac{\frac{\gamma}{1-\tau}\left[\frac{(1-b)(1-c)}{1-\theta}-\delta+b\right]+\frac{d S}{d r}}{\frac{d S}{d r}(1-\theta)+\frac{\gamma(1-b \tau)}{1-\tau}}
$$

In order to identify the distortions associated with the interaction of inflation and personal taxation in a closed economy, (A3) can be used to indicate the effect of inflation on the after-tax price of retirement consumption:

(A4) $\left(\frac{d p_{2}^{a}}{d \pi}\right)^{\text {closed }}=T\left[1-\left(\frac{d r}{d \pi}\right)^{\text {closed }}(1-\theta)\right] p_{2}^{a} \frac{1}{1+r(1-\theta)-\pi}$

Similarly, the distortions associated with the interaction of inflation and corporate taxation in closed economies depend on the effect of inflation on marginal products of capital: 
(A5) $\left(\frac{d f^{\prime}}{d \pi}\right)^{\text {closed }}=\frac{1}{1-\tau}\left[\left(\frac{d r}{d \pi}\right)^{\text {closed }}(1-b \tau)-(1-\delta)\right]$

The values of $\left(\frac{d p_{2}^{a}}{d \pi}\right)^{\text {closed }}$ and $\left(\frac{d f^{\prime}}{d \pi}\right)^{\text {closed }}$ implied by (A4) and (A5) can then be used to determine the

relevant welfare components of the effect of inflation [as in $\frac{d D W L_{p}}{d \pi}$ in $(31), \frac{d D W L_{c}}{d \pi}$ in $(33), \frac{d R E V_{p}}{d \pi}$ in

(32), and $\frac{d R E V_{c}}{d \pi}$ in (34)] in closed economies. 
Figure 1: World Welfare and Inflation Disparities

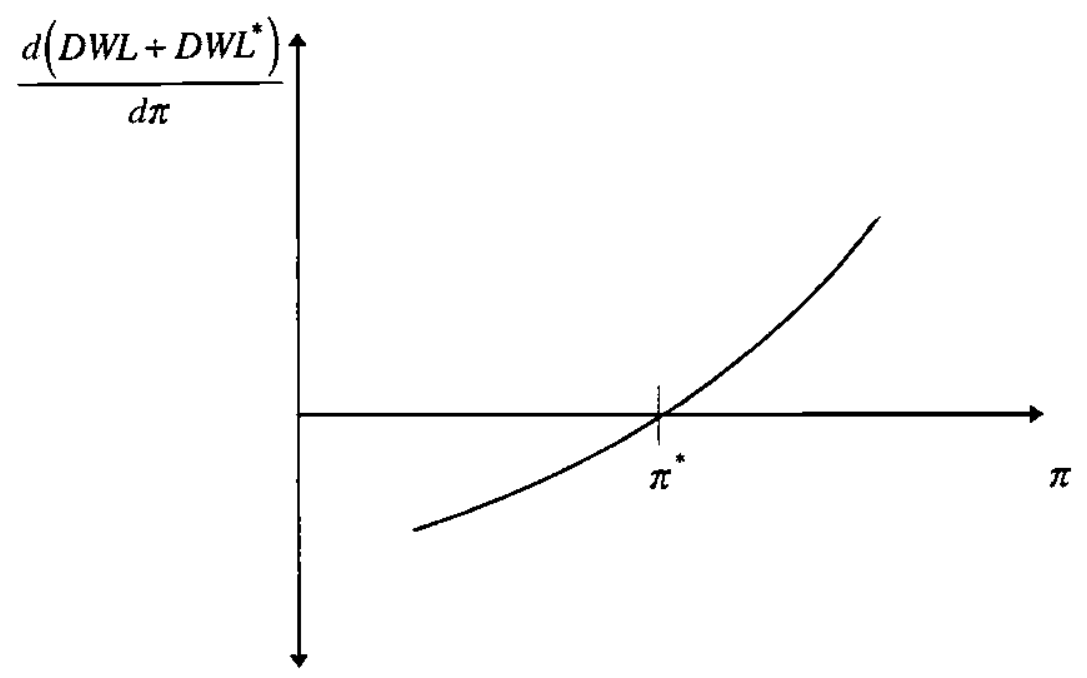

Note: The figure depicts the relationship between disparities in inflation rates $\left(\pi-\pi^{*}\right)$ and the effect of inflation on world welfare. It is evident from the figure that $\frac{d\left(D W L+D W L^{*}\right)}{d \pi}$ takes the same sign as $\left(\pi-\pi^{*}\right)$. 
Table 1

Summary of influence of domestic inflation on worldwide interest rates, savings, and investment

A

$\delta<b \tau$

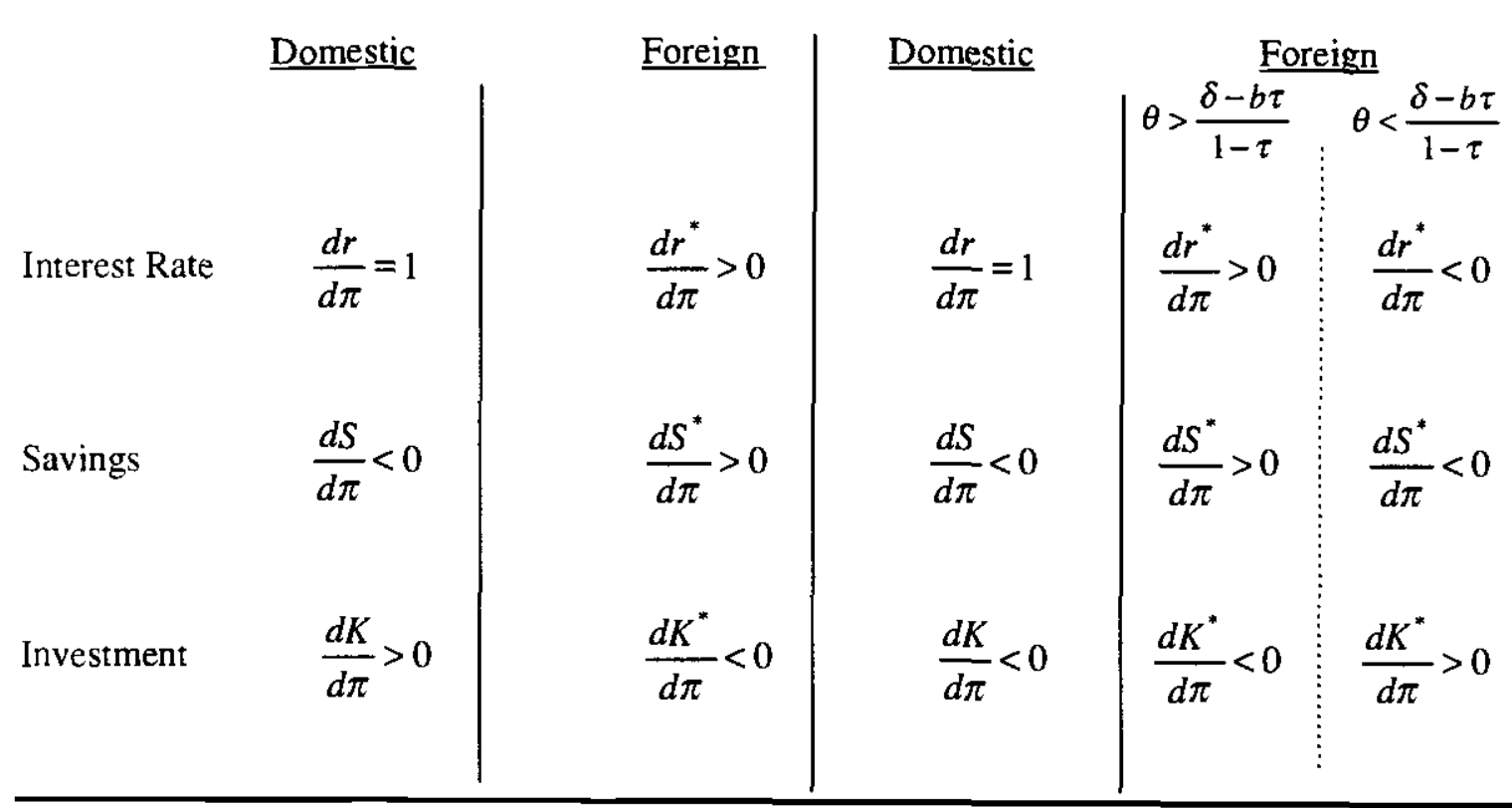

Note: Interest rates, inflation, savings levels and investment are denoted by $\mathrm{r}, \pi, \mathrm{S}$ and $\mathrm{K}$ respectively. Foreign variables are denoted with an asterisk $\left(^{*}\right)$. $\tau$ denotes the domestic corporate tax rate, $\theta$ denotes the domestic personal tax rate on interest income, $b$ denotes the fraction of investment financed by debt domestically and $\delta$ denotes the degree of historic depreciation accounting for tax purposes (where $\delta=0$ corresponds to economic depreciation). The above calculations assume that the domestic tax rate on interest income equals the domestic tax rate on capital gains $(\theta=\mathrm{c})$ and a zero elasticity of savings with respect to the real rate of return $\left(\eta_{s r}=0\right)$. 
Table 2

Sensitivity of $\frac{d r^{*}}{d \pi}$ to Home Country Parameters

(1)

$\tau=0.20$

$b=1.0$

$\delta=0.0$

0.0197

0.0098

0.0000

$\delta=0.2$

$b=0.5$

$\delta=0.0$

0.0098

0.0000

$-0.0099$

$b=0.2$

$\delta=0.2$

$\delta=0.0$

0.0039

$-0.0059$

$-0.0158$

$\delta=0.2$ $\tau=0.35$

$\tau=0.50$

0.0424

0.0788

$0.0303 \quad 0.0630$

0.0182

0.0473

0.0212

0.0394

$0.0091 \quad 0.0236$

$\begin{array}{ll}-0.0030 & 0.0079\end{array}$
0.0085

0.0158

$-0.0036$

0.0000

$-0.0158$

$-0.0158$

\begin{abstract}
Notes: Column 1 presents inflation-induced changes in foreign interest rates when the domestic corporate tax rate, $\tau$, is $20 \%$. Columns 2 and 3 report results for the same calculation when the domestic corporate tax rate is $35 \%$ and $50 \%$, respectively. b denotes the fraction of domestic investment financed at the margin by debt and $\delta$ is a measure of the degree to which depreciation accounting for tax purposes is sensitive to inflation $(\delta=0$ corresponds to zero sensitivity, or economic depreciation). The calculations take the domestic tax rate on interest income to be equal to the domestic tax rate on capital gains $(\theta=c)$. The fraction of foreign investment financed at the margin by debt, $b^{*}$, is taken to equal 0.5 and the foreign corporate tax rate, $\tau^{*}$, is taken to equal $35 \%$. The calculations also assume a zero elasticity of savings with respect to the real rate of return $\left(\eta_{s r}=0\right)$ and that the domestic economy is one tenth the size of the world economy $(\psi=10$, which roughly characterizes Germany).
\end{abstract}


Table 3

Deadweight Loss and Revenue Effects of Domestic Inflation in Open and Closed Economies, Personal Income Taxation

(1)

$\left(\frac{d r}{d \pi}\right)^{c l o s e d}$

$b=1.0$

$\delta=0.0$

$\delta=0.1$

1.5385

1.3849

$\delta=0.2$

1.2313

$b=0.5$

$\delta=0.0$

$\delta=0.1$

1.2127

$\delta=0.2$

1.0917

0.9708

$b=0.2$

$\begin{array}{ll}\delta=0.0 & 1.0761 \\ \delta=0.1 & 0.9689 \\ \delta=0.2 & 0.8616\end{array}$

(2)

$$
\left(\frac{d p_{2}^{a}}{d \pi}\right)^{c l o s e d}
$$

0.0000

1.3721

2.7440

2.9102
3.9908
5.0711

0.2490

4.1302
5.0886
6.0468

(4)

$\left(\frac{d D W L_{p}}{d \pi}\right)^{\text {closed }}\left(\frac{d R E V_{p}}{d \pi}\right)^{\text {closed }}$

$0.0000 \mathrm{GDP}$
0.1174
0.2348

$0.0000 G D P$

\subsection{5}

0.2909
0.3414

0.4339

0.3085
0.4231
0.5376

0.4231

0.5376

0.3534
0.4354
0.5173

0.4378
0.5394
0.6410

(5)

$\left(\frac{d D W L_{p}}{d \pi}\right)^{\text {open }}\left(\frac{d R E V_{p}}{d \pi}\right)^{\text {open }}$
(7)

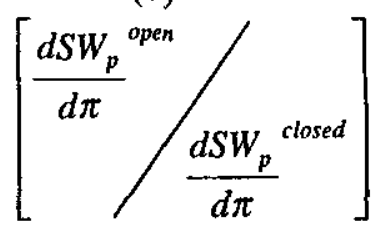

$\begin{array}{ll}0.4115 G D P & 0.5100 G D P \\ 0.4115 & 0.5100 \\ 0.4115 & 0.5100\end{array}$

$-\infty$

3.5044

1.7524

1.6523

1.2049

0.9482

Notes: Column 1 indicates the responsiveness of nominal interest rates to inflation in a closed economy. Column 2 presents inflation-induced changes in after-tax prices of retirement consumption in closed economies. Column 3 presents inflation-induced changes in portions of deadweight losses in closed economies corresponding to intertemporal consumption distortions. Column 4 presents inflation-induced changes in personal income tax revenues in closed economies. Column 5 presents inflation-induced changes in deadweight losses in open economies corresponding to intertemporal consumption distortions. Column 6 presents inflation-induced changes in personal income tax revenues in open economies. Column 7 presents ratios of changes in domestic welfare arising from intertemporal consumption distortions in open and closed economies. $b$ denotes the fraction of domestic investment financed at the margin by debt and $\delta$ is a measure of the degree to which depreciation accounting for tax purposes is sensitive to inflation ( $\delta=0$ corresponds to zero sensitivity, or economic depreciation). The calculations take the domestic tax rate on interest income to be equal to the domestic tax rate on capital gains $(\theta=\mathrm{c})$. The domestic inflation rate, $\pi$, is assumed to be $2.0 \%$ and the nominal interest rate, $\mathrm{r}$, is assumed to be $7.0 \%$. The calculations also assume a zero elasticity of savings with respect to the real rate of return $\left(\eta_{s r}=0\right)$, and that the shadow value of tax revenue is $1.4(\lambda=0.4)$. 
Table 4

Deadweight Loss and Revenue Effects of Domestic Inflation in Open and Closed Economies, Corporate Income Taxation

(1)

$\left(\frac{d f^{\prime}}{d \pi}\right)^{o p e n}$

$b=1.0$

$\delta=0.0$

$\delta=0.1$

$\delta=0.2$

-0.5385
-0.3846
-0.2308

-0.0108
-0.0077
-0.0046

$b=0.5$

$\delta=0.0$

$-0.2692$

$\delta=0.1$

$-0.1154$

$\delta=0.2$

0.0385

$b=0.2$

$\begin{array}{ll}\delta=0.0 & -0.1077 \\ \delta=0.1 & 0.0462 \\ \delta=0.2 & 0.2000\end{array}$

(2)

0.0081

0.0112

0.0142

0.0225

0.0256 $\left[f^{\prime}-(r-\pi)\right]$

(4)

(5)

(6)

$\left(\frac{d R E V_{c}}{d \pi}\right)^{o p e n}$

1.3725GDP

$-0.9091$

$-0.5085$

\subsection{9}

0.0469

0.0012

0.0002
0.0004
0.0006

0.0013

0.0017

0.0022

$-0.0749$

$-0.0421$

$-0.4636$

$-0.1887$

0.0170

0.0599

$-0.0602$

0.0286

0.0022

$\begin{array}{ll}0.0007 & 0.0018 \\ 0.0010 & 0.0022 \\ 0.0013 & 0.0026\end{array}$

0.1352

$-0.1552$

0.0637

0.2648

(7)

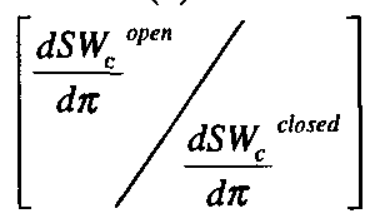

$-\infty$

$-1518.1529$

$-424.4788$

$-364.8884$

$-108.3006$

27.0485

Notes: Column 1 indicates the responsiveness of marginal products of capital to inflation in open economies. Column 2 presents tax and inflationinduced differences between marginal products of capital and pre-tax real rates of return. Column 3 presents inflation-induced changes in portions of deadweight losses in closed economies corresponding to investment distortions. Column 4 presents inflation-induced changes in corporate tax revenues in closed economies. Column 5 presents inflation-induced changes in portions of deadweight losses in open economies corresponding to investment distortions. Column 6 presents inflation-induced changes in corporate tax revenues in open economies. Column 7 presents ratios of inflation-induced changes in social welfare due to corporate taxation in open and closed economies. b denotes the fraction of domestic investment financed at the margin by debt and $\delta$ is a measure of the degree to which depreciation accounting for tax purposes is sensitive to inflation ( $\delta=0$ corresponds to zero sensitivity, or economic depreciation). The calculations take the domestic tax rate on interest income to be equal to the domestic tax rate on capital gains $(\theta=c)$. The domestic inflation rate, $\pi$, is assumed to be $2.0 \%$ and the nominal interest rate, $r$, is assumed to be $7.0 \%$. The calculations also assume a zero elasticity of savings with respect to the real rate of return $\left(\eta_{s r}=0\right)$, and that the shadow value of tax revenue is $1.4(\lambda=0.4)$. 
Table 5

Welfare Effects of Domestic Inflation in Open and Closed Economies, Summary Table

(1) $\left(\frac{d S W_{p}}{d \pi}\right)^{\text {closed }}$

$b=1.0$

$\begin{array}{ll}\delta=0.0 & 0.0000 \mathrm{GDP} \\ \delta=0.1 & -0.0592\end{array}$

$\delta=0.2 \quad-0.1184$

$b=0.5$

$\begin{array}{ll}\delta=0.0 & -0.1256 \\ \delta=0.1 & -0.1722 \\ \delta=0.2 & -0.2188\end{array}$

$b=0.2$

$\delta=0.0$

$-0.1782$

$\delta=0.1$

$-0.2196$

$\delta=0.2$
(2)

$\left(\frac{d S W_{c}}{d \pi}\right)^{\text {closed }}$

0.0000 GDP
0.0003
0.0006

0.0003

0.0003

0.0003

0.0000
-0.0001
-0.0003

(3)

$\left(\frac{d S W_{p}}{d \pi}\right)^{o p e n}$

$-0.2075 G D P$

$-0.2075$

$-0.2075$

-0.2075
-0.2075
-0.2075

$-0.2075$

$-0.2075$

$-0.2075$
(4)

$\left(\frac{d S W_{c}}{d \pi}\right)^{o p e n}$

$-0.8446 \mathrm{GDP}$

$-0.5035$

$-0.2503$

$-0.1105$

$-0.0334$

0.0069
(5)

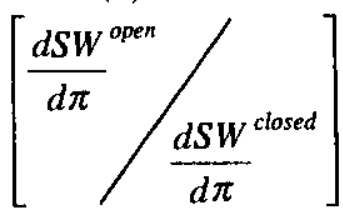

$-\infty$

12.0756

3.8859

2.5387

1.4013

0.9177

1.1751

0.9588

0.9066

Notes: Column 1 presents inflation-induced changes in social welfare due to personal taxation in closed economies. Column 2 presents inflationinduced changes in social welfare due to corporate taxation in closed economies. Column 3 presents inflation-induced changes in social welfare due to personal taxation in open economies. Column 4 presents inflation-induced changes in social welfare due to corporate taxation in open economies. Column 5 presents the ratios of inflation-induced changes in social welfare due to personal and corporate taxation in closed and open economies. $b$ denotes the fraction of domestic investment financed at the margin by debt and $\delta$ is a measure of the degree to which depreciation accounting for tax purposes is sensitive to inflation ( $\delta=0$ corresponds to zero sensitivity, or economic depreciation). The calculations take the domestic tax rate on interest income to be equal to the domestic tax rate on capital gains $(\theta=c)$. The domestic inflation rate, $\pi$, is assumed to be $2.0 \%$ and the nominal interest rate, $r$, is assumed to be $7.0 \%$. The calculations also assume a zero elasticity of savings with respect to the real rate of return $\left(\eta_{S r}=0\right)$, and that the shadow value of tax revenue is $1.4(\lambda=0.4)$. 
Table 6

Deadweight Loss and Revenue Effects of Domestic Inflation on Foreign Economy

(1)

$$
\left(\frac{d D W L_{p}^{*}}{d \pi}\right)
$$

(3)

(4)

$\left(\frac{d S W_{p}^{*}}{d \pi}\right)$

$\left(\frac{d D W L_{c}^{*}}{d \pi}\right)$

$b=1.0$

$$
\delta=0.0
$$

$\delta=0.1$

-0.3244 GDP

$\delta=0.2$

$-0.2318$

$-0.4019 \mathrm{GDP}$

$-0.2873$

$-0.1727$

$b=0.5$

$\begin{array}{ll}\delta=0.0 & -0.1626 \\ \delta=0.1 & -0.0701\end{array}$

$-0.2014$

$-0.0869$

$\delta=0.2$

0.0223

0.0276

$b=0.2$

$\begin{array}{ll}\delta=0.0 & -0.0656 \\ \delta=0.1 & 0.0268 \\ \delta=0.2 & 0.1192\end{array}$

-0.0813
0.0332
0.1477

$-0.0813$

0.1477

$0.1636 \mathrm{GDP}$
0.1169

0.0703

$0.1965 G D P$
0.1404
0.0844

0.0820

0.0354

$-0.0113$

0.0985
0.0425
-0.0135

0.0331
-0.0135
-0.0601

0.0397

$-0.0162$

$-0.0722$
(5)

(6)

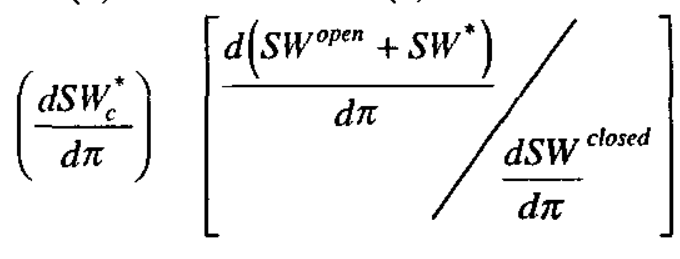

$\begin{array}{ll}-0.0881 G D P & -0.2317 G D P \\ -0.0630 & -0.1656 \\ -0.0378 & -0.0995\end{array}$

$-\infty$

12.9025

4.1343

2.8112

1.4869

0.8963

$\begin{array}{rrr}-0.0441 & -0.1161 & 2.8112 \\ -0.0190 & -0.0501 & 1.4869 \\ 0.0061 & 0.0159 & 0.8963\end{array}$

$\begin{array}{rr}-0.0178 & -0.0469 \\ 0.0073 & 0.0192 \\ 0.0324 & 0.0852\end{array}$

1.2524

0.9332

0.8108

Notes: Column 1 presents inflation-induced changes in portions of deadweight loss in the rest of the world corresponding to intertemporal consumption distortions. Column 2 presents inflation-induced changes in personal income tax revenues in the rest of the world. Column 3 presents inflation-induced changes in foreign welfare arising from intertemporal consumption distortions. Column 4 presents inflation-induced changes in the portions of deadweight loss in the rest of the world corresponding to investment distortions. Column 5 presents inflation-induced changes in corporate tax revenue in the rest of the world. Column 6 presents inflation-induced changes in social welfare in the rest of the world arising from corporate taxation. Column 7 presents the ratios of inflation-induced changes in world welfare when inflating economies are open and closed. $b$ denotes the fraction of domestic investment financed at the margin by debt and $\delta$ is a measure of the degree to which depreciation accounting for tax purposes is sensitive to inflation ( $\delta=0$ corresponds to zero sensitivity, or economic depreciation). The calculations take the domestic tax rate on interest income to be equal to the domestic tax rate on capital gains $(\theta=c)$. The domestic inflation rate, $\pi$, is assumed to be $2.0 \%$ and the nominal interest rate, $r$, is assumed to be $7.0 \%$. The calculations also assume a zero elasticity of savings with respect to the real rate of return $\left(\eta_{s r}=0\right)$, and that the shadow value of tax revenue is $1.4(\lambda=0.4)$. Foreign parameters are fixed at $b^{*}=0.5, \delta^{*}=0.1, \tau^{*}=35 \%$, and $\theta^{*}=35 \%$. 


\section{References}

Abuaf, Niso and Philippe Jorion (1990). "Purchasing Power Parity in the Long Run," Journal of Finance 45: 157-74.

Auerbach, Alan (1978). "Appendix" to "Inflation and Taxes in a Growing Economy with Debt and Equity Finance" Journal of Political Economy, 70: S71.

Auerbach, Alan J. and James R. Hines Jr. (1988). "Investment Tax Incentives and Frequent Tax Reforms," American Economic Review, 78:2, 211-216.

Ballard, Charles L., John B. Shoven, and John Whalley (1985). "General Equilibrium Computations of the Marginal Welfare Costs of Taxes in the United States," American Economic Review, 75:128-138.

Bayoumi, Tamim and Joseph Gagnon (1996). "Taxation and Inflation: A New Explanation for Capital Flows," Journal of Monetary Economics, 38:2, 303-330.

Commission of the European Communities (1992). Report of the Committee of Independent Experts on Company Taxation (Luxembourg: Office for Official Publications of the European Communities).

Cooper, Ian and Evi Kaplanis (1994). "What Explains the Home Bias in Portfolio Investment," Review of Financial Studies, 7:1, 45-60.

Darby, Michael (1975). "The Financial and Tax Effects of Monetary Policy on Interest Rates," Economic Inquiry, 13: 266-276.

Desai, Mihir (1997). "Inflation, Taxation and Openness," Manuscript, Harvard University.

Feldstein, Martin (1976). "Inflation, Tax Rules, and the Rate of Interest: A Theoretical Analysis," American Economic Review 66: 809-820.

Feldstein, Martin (1978). "The Welfare Cost of Capital Income Taxation," Journal of Political Economy $86:$ :S2-S51.

Feldstein, Martin (1983). Inflation, Tax Rules, and Capital Formation. Chicago: University of Chicago Press.

Feldstein, Martin (1995). "Tax Avoidance and the Deadweight Loss of the Income Tax," Working Paper No. 5055. Cambridge, MA: National Bureau of Economic Research.

Feldstein, Martin (1997). "Capital Income Taxes and the Benefit of Price Stability," Working Paper, Harvard University.

Feldstein, Martin, Jerry Green and Eytan Sheshinski. (1978) "Inflation and Taxes in a Growing Economy with Debt and Equity Finance" Journal of Political Economy 70: S53-S70.

Feldstein, Martin, and Charles Horioka. (1980) "Domestic Saving and International Capital Flows" Economic Journal 90:314-29.

Frankel, Jeffrey A. (1991). "Quantifying International Capital Mobility in the 1980s." in National Saving and Economic Performance, edited by B. Douglas Bemheim and John B. Shoven. Chicago: University of Chicago Press. 
French, Kenneth R. and James M. Poterba (1991), "Investor Diversification and International Equity Markets," American Economic Review, 81:2, 222-226.

Froot, Kenneth A., Michael Kim, and Kenneth Rogoff. (1995). "The Law of One Price over 700 years," Working Paper No. 5132. Cambridge, MA: National Bureau of Economic Research.

Gordon, Roger. (1986) "Taxation of Investment and Savings in a World Economy." American Economic Review 76:1086-1102.

Gordon, Roger and Hal Varian (1989). “Taxation of Asset Income in a World Securities Market." Journal of International Economics, 26: 205-226.

Graham, Edward M. and Paul R. Krugman (1991). Foreign Direct Investment in the United States. Washington D.C., Institute for International Economics.

Hansson, Ingemar and Charles Stuart (1986), "The Fisher Hypothesis and International Capital Markets," Journal of Political Economy, 94:1330-1337.

Hartman, David (1979). "Taxation and the Effects of Inflation on the Real Capital Stock in an Open Economy," International Economic Review 20:417-425.

Hines, James R., Jr. (1996). “Tax Policy and the Activities of Multinational Corporations,” Working Paper No. 5589. Cambridge, MA: National Bureau of Economic Research.

Howard, David and Karen Johnson (1982). "Interest Rates, Inflation, and Taxes: The Foreign Connection," Economics Letters 9: 181-4.

International Monetary Fund. (1991) Determinants and Systemic Consequences of International Capital Flows Washington D.C., International Monetary Fund.

International Monetary Fund. (1997) International Financial Statistics Washington D.C., International Monetary Fund.

Johnson, David R. (1990). "Co-integration, Error Correction, and Purchasing Power Parity between Canada and the United States," Canadian Journal of Economics 23 (November): 839-55.

Levi, Maurice (1977). "Taxation and 'Abnormal' Intemational Capital Flows," Journal of Political Economy, 85:635-646.

Mishkin, Frederic S. (1992) "Is the Fisher Effect for Real?" Journal of Monetary Economics 30: 195-215.

Mundell, Robert (1963). "Inflation and Real Interest" Journal of Political Economy 71:280-3.

Romer, David (1993). “Openness and Inflation: Theory and Evidence," Quarterly Journal of Economics, 108:4, 869-903.

Sinn, Hans-Werner (1991). "The non-neutrality of inflation for international capital movements," European Economic Review, 34: 1-22. 
Sorenson, Peter Birch (1986). "Taxation, Inflation, and Asset Accumulation in a Small Open Economy," European Economic Review, 30:1025-1041.

Tesar, Linda L. and Ingrid M. Werner (1995), "Home Bias and High Turnover," Journal of International Money and Finance, 14:4, 467-492.

Tesar, Linda L. and Ingrid M. Werner (1994), "International Equity Transactions and U.S. Portfolio Choice," in The Internationalization of Equity Markets, edited by Jeffrey A. Frankel, University of Chicago Press.

Tobin, James (1965). "Money and Economic Growth," Econometrica 33: 671-684.

Wahl, Jenny Bourne (1988). "Tax Treatment of foreign exchange gains and losses and the Tax Reform Act of 1986," National Tax Journal, 42:59-68.

Wei, Shang-Jin, and David C. Parsley (1995). "Purchasing Power Dis-Parity during the Floating Rate Period." Working Paper, Harvard University.

The World Bank (1995). World Tables 1995. Johns Hopkins University Press. 